\title{
TÁRSULÁSI VAGY MEGSZÜNÉSI KÉNYSZER: KÖZOKTATÁS-SZERVEZÉS A TÖBBCÉLÚ KISTÉRSÉGI TÁRSULÁSOKBAN
}

\author{
(A Pressure to Co-operate or Close: Public Education \\ Management in the Ranks of Multifunctional Local \\ Government Associations)
}

\author{
KOVÁCS KATALIN
}

\begin{abstract}
Kulcsszavak:
többcélú kistérségi társulások iskolabezárások kényszer-szülte társulások közoktatás-szervezés a kistelepülések, aprófalvak világában

A tanulmány elsö része összegzi azokat a körülményeket, amelyek az ezredfordulót követö években lépéskényszert teremtettek az önkormányzati intézményfenntartásban, azon belül is a közoktatásban és különösen a kistelepülések körében (demográfiai erózió, forráskivonás). A második rész a kistérségi szintü közfeladat-ellátás néhány sajátosságát és a különböző településszerkezetü régiók eltérö érintettségét mutatja be. Az elemzés hangsúlya a kistelepülésekre, aprófalvas régiókra esik, ahol az önálló intézményfenntartás, köztiik az iskolák fenntartása a legnagyobb vérveszteséget szenvedte el a községek körében. A folyamat nyertesei a hagyományos intézményfenntartó és az újsütetü többcélú kistérségi társulások, de az alapítványok, egyházak fenntartói szerepe is szignifikánsan erösödött. A szerző az önkormányzatok közös intézményfenntartását elkerülhetetlennek tartja a kistelepülések világában, ugyanakkor a túl gyorsan kikényszerített iskolabezárások és a túl nagy területet átfogó társulások veszélyeire is felhivja a figyelmet ${ }^{\text {. }}$.
\end{abstract}

\section{Bevezetés}

A tanulmány alapvető célja, hogy egy kutatás kezdetén ${ }^{2}$ összegezze, ami a kistérségi társulásokról, azok közoktatás-szervezésben betöltött szerepéről az elérhető adatok és szakirodalmi feldolgozások alapján tudható. Az elemzés fókuszában az iskolafenntartók összetételében bekövetkezett átrendeződés áll, amely a települési önkormányzatok fenntartásában müködő iskolák nagymértékü csökkenését és a társulásban, egyházi és alapítványi fenntartásban müködők bővülését jelenti. A folyamatot a többcélú kistérségi társulások megalakításához feltételként támasztott szabályok indították el 2004-2005-ben, amelyekhez továbbiak társultak 2007-ben (ÖNHIKI szabályozás, Közoktatási törvény); a kapcsolódó törvények és rendeletek együttes erejének köszönhető a változások viharos gyorsasága.

A nyíltan a kisméretü intézmények megszüntetésére irányuló intézkedések nyomán a kisiskolák müködési feltételei gyakorlatilag ellehetetlenültek. A vitát, amely újra fellángolt 2005-2006-ban arról, hogy érdemes-e többlet áldozatot hozni megmenté- 
sükért, azért a szocializációs többletért, amellyel rendelkeztek, a hivatkozott rendelkezések mintegy lezárták. Ha azonban az okokat keressük, amelyek a kivételes hatékonyságú kormányzati reakciókat kiváltották, elsősorban az elmaradt születéseket, az így keletkezett gyermekhiányt, tágabban a társadalom globális elöregedését és az önkormányzati finanszírozás ellehetetlenülését kell megemlítenünk.

Hogy az intézmény összevonásoknak és megszűnéseknek milyen hatása lesz az érintett helyi közösségekre, az még nem tudható. Az az empirikus kutatás, amelynek megalapozásához ez a tanulmány hozzájárult, valamivel több információval szolgálhat, ám a következményekkel hosszabb távon kell számolni.

\section{Néhány kiváltó tényezö}

A rendszerváltozás nyomán kialakult - a korábbi centralizációra túlzó decentralizációval reagáló, ráadásul széles jogosítványokkal bíró - önkormányzati rendszer hatékonysági és irányítási problémái hamar felszínre kerültek, amelyre a kormányzat hétévente reagált. Az első olyan rendelkezés, amely a szabályozás eszközeivel mintegy utólag keretbe foglalta a települések között önkéntes alapon, elszórtan létrejött együttműködéseket, 1997-ben született ${ }^{3}$ (a továbbiakban: társulási törvény). Ezt hét évvel követte a többcélú társulások életre hívását ösztönző „,kistérségi törvény"4 (ide értve kísérő rendeleteit is), amely jellegében gyökeresen eltért hét éves elözményétől. Mindenekelőtt

- maga diktálta a térbeli és szervezeti struktúrákat, amikor a statisztikai kistérségekre telepítette a többcélú kistérségi társulásokat (a továbbiakban TKT);

- kis mozgástérrel, de megszabta a társulások kötelező tevékenységeit;

- a társulási törvény pluralizmusával ${ }^{5}$ szemben - ebben az esetben is némi rugalmassággal ugyan, de - egyféle megoldást javasolt, t.i. a többcélú kistérségi társulás törvényben fixált szervezeti modelljét.

A kistérségi törvény a területfejlesztési tevékenységet kötelezővé tette minden, a statisztikai kistérségek szerint szerveződő kistérségi területfejlesztési tanács számára. A többcélú kistérségi társulásoknak emellett a közoktatást, a szociális és gyermekjóléti, továbbá az egészségügyi feladatellátást - illetve azok néhány, a törvényben meghatározott vagy/és szabadon választott szegmensét - is vállalniuk kellett. A törvény hatályba lépését követő második évben 90\%-os volt az ország lefedettsége, öt év múltán pedig hiánytalan, amelynek egyrészről az az oka, hogy a legnehezebb helyzetben lévő, kistelepülési önkormányzatok nem mondhattak le azokról a forrásokról, amelyekre a többcélú társuláson keresztül váltak jogosulttá, míg a kedvezőbb helyzetben lévő települések számára is célszerünek látszott megteremteni azokat a feltételeket, amelyek kényelmesebb és jobb minőségü ellátást nyújthattak.

Az alábbiakban azt mutatjuk be, hogy milyen körülményekre reagált a 2004-ben elfogadott kistérségi törvény, a témánk szempontjából kiemelt ágazat, a közoktatás területéről hozva a példákat. 
a) A kormányzati kapacitások gyengesége

Majdnem másfél évtizeddel azután, hogy megszünt, illetve szétzilálódott a középszintü közszolgáltatás-szervezés (városkörnyéki, megyei szinten), közvetítő és ellenőrző mechanizmusok hiányában a szakpolitikák „,szakirányítási eredményességi” problémákkal küszködtek. A közoktatás területén

- a megyei pedagógiai intézetek feloszlottak, vagy ha nem is oszlottak fel, mandátumuk elbizonytalanodott, tanügy-igazgatási szerepüket elvesztették;

- a szak- és szakmai szolgáltatások, mint kötelező feladatok ugyan megyei fenntartásban maradtak, de területi lefedettségük a kívánatos mérték alatt maradt, még a kulcsterületeken sem voltak képesek szolgáltatásaik kistérségi szintü terítésére;

- a megyei szintü tervek nem váltották be a hozzájuk füzött reményeket.

A többcélú kistérségi társulási forma a középszinteken keletkezett ür betöltését szolgálta alsó-középszinten úgy, hogy a központi irányítás súlya sértetlen maradjon. Azonban ezzel a lehetőséggel az érintett ágazatok nagyon különböző módon éltek. Az oktatáspolitika két célra használta fel a kistérségi társulásokat, egyrészt és főként a szervezeti koncentrációra, amelynek a tervezést is szolgálatába állította, másrészt a kulcsfontosságú szakmai szolgáltatásokhoz való hozzáférés javítására, de oktatásirányítási bázist nem alakított ki ezen a szinten.

\section{b) Súlyos és a prognózisok szerint folytatódó demográfiai erózió}

Jóllehet 1990 és 1995 között mind az óvodáskorú, mind az iskoláskorú populációban csökkent a gyermekszám, az intézmények száma emelkedett, s amikor a csökkenés elindult, nem volt arányos a demográfiai erózió mértékével. Még nagyobb aránytalanság alakult ki a pedagógusok számát illetően; a szakértők pedagógus túlfoglalkoztatásról beszéltek, s kimutatták, hogy 2003-ban Magyarország utolsó helyen állt az egy pedagógusra jutó tanulók számát tekintve az OECD országok körében (Radó 2004).

\section{TÁBLÁZAT}

Változások az alapfokú oktatás szereplöi és intézményei között (Changes amongst the Actors and Institutions of Primary Education)

\begin{tabular}{ccccccc}
\hline \multirow{2}{*}{ Év } & \multicolumn{2}{c}{ Óvodai } & Iskolai & Óvónök & Tanárok Óvodások & Iskolások \\
\cline { 2 - 7 } & $\begin{array}{c}\text { feladatellátó helyek } \\
(\mathrm{db})\end{array}$ & \multicolumn{5}{c}{ száma (fö) } \\
\hline 1990 & 4718 & 3723 & 33635 & 96791 & 391950 & 1166076 \\
1995 & 4720 & 4006 & 32320 & 93035 & 400527 & 987561 \\
2000 & 4640 & 3875 & 32000 & 89750 & 353100 & 957850 \\
2008 & 4355 & 3363 & 29920 & 78073 & 325677 & 788639 \\
$2008 / 1990$ & $92 \%$ & $90 \%$ & $89 \%$ & $88 \%$ & $83 \%$ & $68 \%$ \\
\hline
\end{tabular}

Forrás: Oktatás-statisztikai Évkönyv (2009). 
Miközben túlfoglalkoztatás jellemezte a közoktatást, s a hetvenes-nyolcvanas években épített szocreál iskolaépületek félgőzzel üzemeltek a korábbi iskolaközpontokban, az infrastruktúra állaga már csak azért is romlott, mert a fenntartó önkormányzatok finanszírozási és fejlesztési egyre szükösebbé váltak. Remény a fordulatra nem látszott: az OECD 2000-hez képest 23\%-os csökkenést becsült Magyarországon az 5-14 évesek számában 2015-re (Education... 2009). A fejlesztésre fordított költségek monoton csökkentek a közoktatásra költött összegeken belül (az alapfokú oktatásban 1990: 9,2\%, 1995: 3,2\%, 2005: 3,0\%, 2008: 2,5\% [Oktatás-statisztikai... 2009, 169]), s ezekből is annyit csíptek el a fenntartók a müködtetésre, amennyit csak tudtak.

\section{c) Külső és belsö hatékonysági problémák}

A kapacitások kihasználatlansága, a túlfoglalkoztatás óhatatlanul megdrágította a közoktatást, ami 2003-ban, a közalkalmazotti bérek emelését követően érte el a „finanszírozhatóság határát” (Radó 2006, 5). A 2. táblázat mutatja, hogy miként alakultak az oktatási kiadások 1990 és 2008 között, azt is érzékeltetve, hogy az alapfokú oktatáson sikerült a legnagyobb megtakarítást elérni (1995-höz viszonyítva mindenképpen: a 0,47 százalékpontos visszaesés kétszerese a középiskolákat érintő megszorításoknak ${ }^{6}$ ).

\section{TÁBLÁZAT}

Oktatás-finanszírozás 1990-2008

(Financing Public Education 1990-2008)

\begin{tabular}{|c|c|c|c|c|c|c|}
\hline \multirow[b]{2}{*}{$\dot{E} v$} & óvoda & Alapfok & Középfok & Felsöfok & \multirow{2}{*}{$\begin{array}{c}\text { Összes } \\
\text { oktatási } \\
\text { kiadás az } \\
\text { ÁHT kiadá- } \\
\text { sainak } \\
\text { \%-ában }\end{array}$} & \multirow{2}{*}{$\begin{array}{c}\ddot{O} \text { sszesen } \\
\text { a GDP } \\
\text { \%-ában }\end{array}$} \\
\hline & \multicolumn{4}{|c|}{ A GDP \%-ában } & & \\
\hline 1990 & 0,74 & 2,38 & 1,47 & 0,81 & 9,56 & 5,68 \\
\hline 1995 & 0,77 & 2,13 & 1,31 & 0,96 & 8,56 & 5,46 \\
\hline 2000 & 0,69 & \multicolumn{2}{|c|}{2,64} & 1,06 & 11,13 & 4,98 \\
\hline 2003 & 0,84 & \multicolumn{2}{|c|}{3,05} & 0,99 & 12,3 & 5,66 \\
\hline 2008 & 0,71 & 1,67 & 1,04 & 0,97 & 9,45 & 4,82 \\
\hline
\end{tabular}

Forrás: Oktatás-statisztikai Évkönyv (2009).

Miközben a közoktatás elérte finanszírozási határait, azonközben nemcsak belső, hanem külső hatékonysági problémákkal is küzdött. Mind a PISA-felmérések, mind az országos kompetenciamérések azt mutatták, hogy az iskola nagyon keveset tud tenni a családi környezetből eredő hátrányok csökkentésére, és ezzel szoros összefüggésben, nagyon magas a középiskolai lemorzsolódás. A középiskolai kudarc különösen jellemző a kisfalvak kisiskoláiból kibocsátott tanulókra, nem azért, mert az iskolák kis mérete eleve elrendeli az alacsony színvonalú oktatást, hanem a családok 
társadalmi összetétele következtében (Hermann 2005; Horn 2005). Ebböl, tehát társadalom- és térszerkezeti okokból következik, hogy a tanulók iskolai teljesítményei tekintetében is müködik a „települési lejtő”, amit a 2008. évi kompetenciamérések alapján készített 1 . ábra illusztrál.

\section{1. ÁBRA}

Képesség-eloszlás a települések jogállása szerint a diákok 75. percentilisnél elért átlagos teljesítménye alapján. Kompetenciamérések 2008

(The Distribution of Students' Average Proficiency at 75 percentile by the Administrative Status of Local Communities)

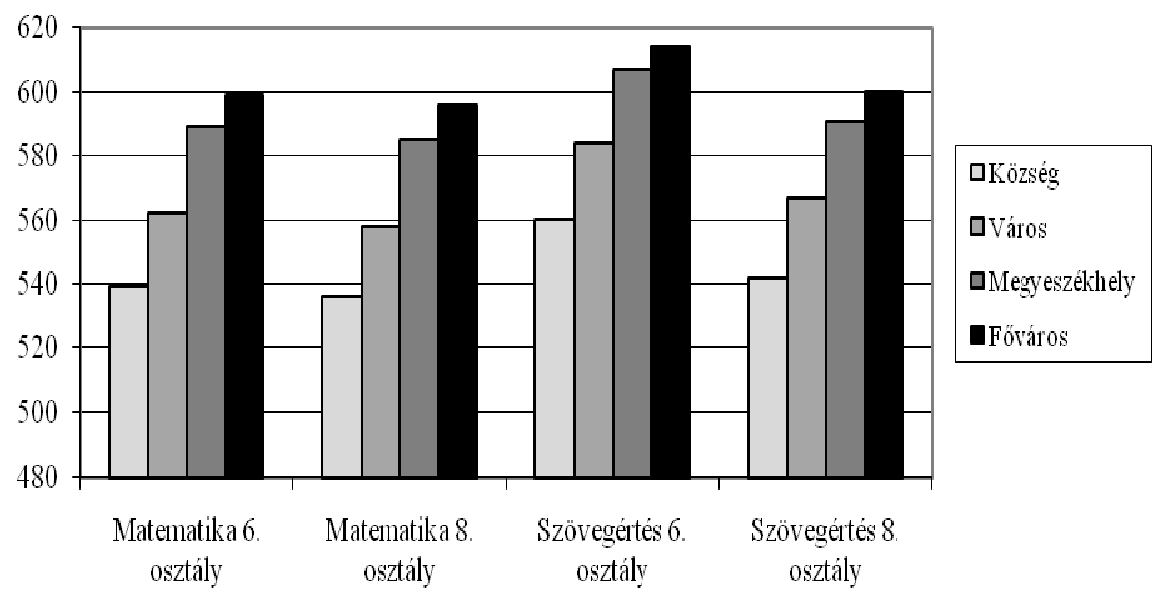

Forrás: Saját szerkesztés az OKM (2008) kiadványban szereplő adatok alapján.

Még mindig nagyon magas számban és rendkívül rossz perspektívákkal kerülnek ki az oktatási rendszerből azok, akik legfeljebb 8-13 évig tanulnak, és nem teszik le az érettségi vizsgát (Péteri 2005; Semjén 2005; Köllö 2009). Ez utóbbi jelenség okát nemcsak, sőt nem is elsősorban az oktatási rendszerben kell keresnünk, tény azonban, hogy a közoktatásnak is van ebben a kérdésben tennivalója, nem is kevés. A 2. ábra nemzetközi kitekintést tesz lehetővé: az OECD tagállamok közül a volt szocialista országokban az alap-fokú és alsó-középfokú végzettséggel rendelkezők munkaerő-piaci részvételét mutatja 1997 és 2007 között. A grafikon jól érzékelteti, hogy a közép-európai országokhoz viszonyítva is nagyon alacsony szintről indultunk 1997-ben, a legalacsonyabbról (36,2\%), és nagyon alacsony szinten maradtunk 2007-re (38,5\%), különösen az OECD országok átlagához mérve. 


\section{2. ÁBRA}

Az alacsony képzettséggel rendelkezök munkaerö-piaci részvétele, 1997-2007 (\%) (Employment Rates of Labour Market Participants with Pre-primary and Primary Education)

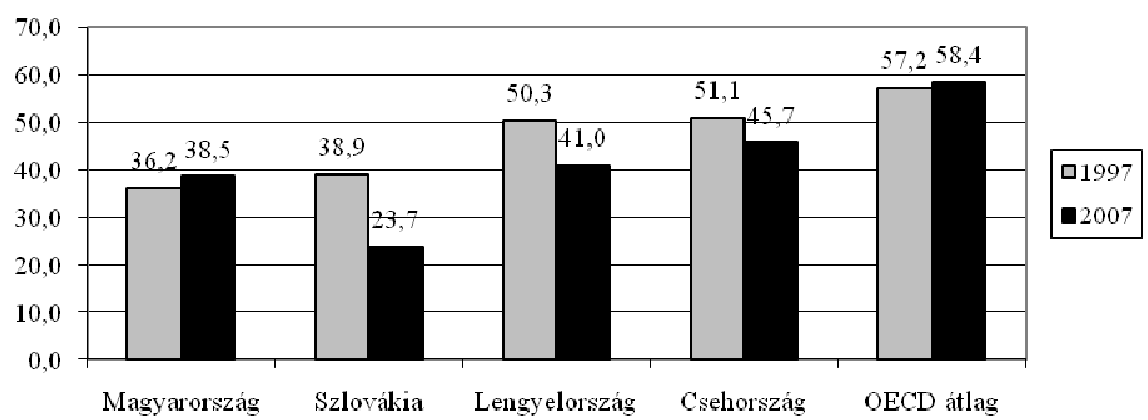

Forrás: Education... (2009).

\section{A kistérségi társulások közfeladatainak finanszírozása 2004-2009}

A kistérségi társulások megalakulásának üteme gyors volt, sokkal gyorsabb, mint korábban, az „,alulról építkező” társulásoké. Már 2004-ben 73 kistérségben megalakult a többcélú társulás, igaz, 23 kistérségben nem a települések teljes körére, csak 60\%-ára ${ }^{7}$. 2005-ben 108, 2006-ban 154, 2007-ben 162-re rúgott a „„öbbcélú” együttmüködések száma, és a korábban részleges lefedettségü kistérségekben az önkormányzatok teljes köre csatlakozott.

Történt ez annak ellenére, hogy 2004-ben csak az egyszeri, beruházásokra költhető „ösztönző" volt biztos, a müködtetést finanszírozó normatív támogatások még csak ígéretként szerepeltek. A mintegy 11,8 milliárd forint beruházási támogatás 32\%-a közoktatási fejlesztéseket finanszírozott, amelyet - a „társulási kényszer alatt álló” ágazatok részesedését kiemelve - az egészségügyi (17\%), a szociális és/vagy gyermekjóléti fejlesztések (együtt 15\%-os) támogatása követett (3. ábra).

A többcélú társulások létrehozása még gyorsabb lehetett volna, ha a kezdeti években nem gátolja azt a normatív támogatások bizonytalansága, továbbá a települések között régóta feszülő, a korábbi körzetesítéssel összefüggő ellentétek, az információhiány, a feladatellátás vállalásához előírt szakmai követelmények teljesítése. Számos, a társulás létrehozását fontolgató települési önkormányzat nem látta biztosítva a közös feladatellátás finanszírozását, amihez az is hozzájárult, hogy a pénzügyi feltételeket szabályozó kormányrendeletek meglehetősen rövid határidőket szabtak a pályázatok, illetve az igénybejelentések benyújtására. 


\section{3. ÁBRA}

A 2004-2005-ben pályázható ösztönzö (beruházási) támogatások megoszlása fejlesztési témakörök szerint

(The Distribution of Development Incentives by Themes in 2004-2005)

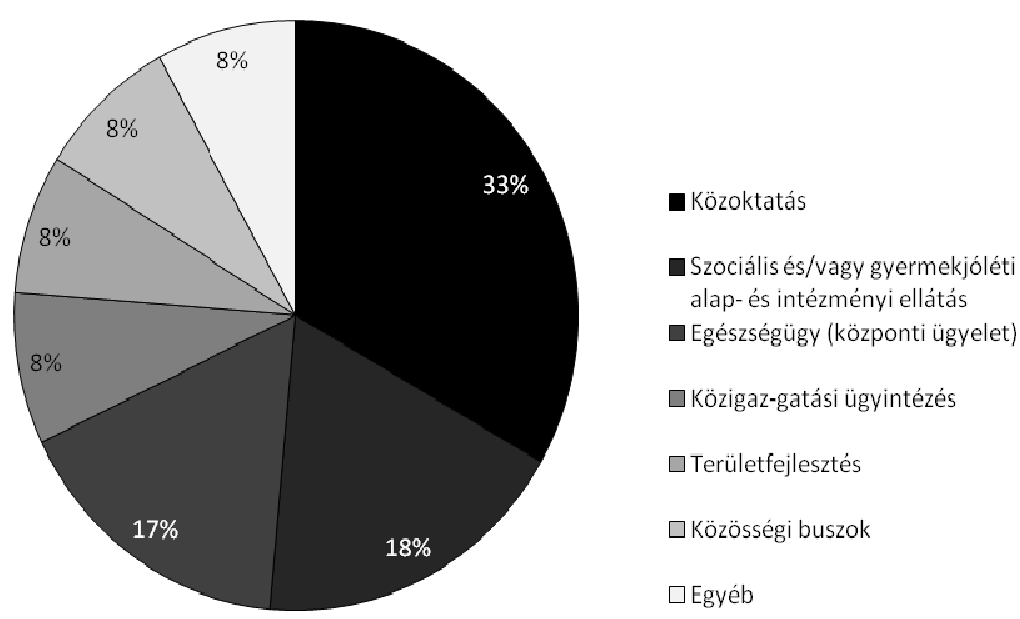

Forrás: Saját szerkesztés a BM honlapján található adatokból.

http://www.bm.hu/web/portal.nsf/html/onkgazd.html/\$FILE/14_2004_tobbcel.pdf?OpenElement, http://www.bm.hu/web/portal.nsf/html/onkgazd.html/\$FILE/16_2005_fejl.pdf?OpenElement, http://www.bm.hu/web/portal.nsf/html/onkgazd.html/\$FILE/17_2005_kozossegibusz.pdf?OpenElement.

A 2005-öt követö felgyorsulásban döntő szerepe volt a kistérségi normatív finanszírozás elindulásának. A költségvetésbe 2006-tól biztos elemként beépülö kistérségi normatíva hatására nemcsak a megalakult kistérségi társulások száma nőtt évről évre, hanem az egy kistérség által átlagosan vállalt feladatoké is: 2005-ben még csak 3,5 normatívával támogatott feladat jutott egy kistérségre, 2007-ben már 5,1; 2009-ben pedig 5,6. Ha a regionális eltéréseket nézzük, határozott többlet mutatkozik az aprófalvas régiók javára (Dél-Dunántúl, Nyugat-Dunántúl, ÉszakMagyarország): itt - érthetően - több feladat együttes ellátására szövetkeztek a települések (4. ábra), minél előrébb haladunk az időben, annál inkább. A két végletet a Nyugat-dunántúli régió és Pest megye képviseli, előbbiben a társulások $80 \%$-a legalább hat feladat ellátását vállalta, Pest megyében a társulások ugyanekkora aránya legfeljebb öt feladatot szervez a kistérségi társulás keretében. 


\section{4. ÁBRA}

A többcélú kistérségi társulások régiók és a vállalt feladatok száma szerint, 2009 (Multifunctional Local Government Associations by Regions and According to the Number of Services Delivered)

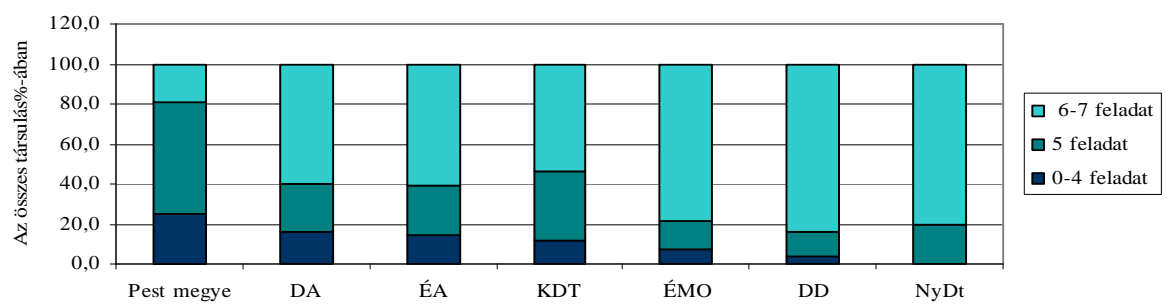

Forrás: Saját szerkesztés a BM honlapján található adatokból. http://www.bm.hu/web/portal.nsf/html/onkgazd.html/\$FILE/23_onkgazd.pdf?OpenElement.

A Belügyminisztérium honlapján a kistérségi normatívákról közölt információk szerint 2009-ben a társulások közül csupán egy volt, az érdi, amelyik semmiféle feladatot nem látott el, ezért nem is részesült normatív támogatásban. Nyolc társulás ${ }^{8}$ nem vállalt sem szociális, sem gyermekjóléti feladatokat, ami azért érdekes, mert ezek közül legalább egy közös szervezését a kistérségi törvény kötelezővé teszi. A közoktatás mellett még nagyfokú együttmüködési kedvet dokumentálhatunk a belső ellenőrzés (93\%), a gyermekjóléti alapszolgáltatások (91\%) és a szociális alapellátás (84\%) területén 2009-ben, s a mozgókönyvtári szolgáltatás megszervezését is vállalta a társulások 65\%-a (3. táblázat). Az egészségügyről nincs információnk, mert az egészségügyi szolgáltatásokat, köztük a hétvégi és hétközi ügyelet kistérségi megszervezését - az OEP finanszírozás felett - nem támogatta többlet-normatíva.

3. TÁBLÁZAT

Kistérségi társulások és vállalt feladatok, 2009

(Tasks Taken by the Multifunctional Local Government Associations in 2009)

\begin{tabular}{lcc}
\hline \multicolumn{1}{c}{ Feladatok } & $\begin{array}{c}\text { Társulások } \\
\text { száma }(\mathrm{db})\end{array}$ & $\begin{array}{c}\text { A szolgáltatást vállaló } \\
\text { társulások a társulá- } \\
\text { sok \%-ában }\end{array}$ \\
\hline Általános feladatok & 172 & 99 \\
Közoktatás & 172 & 99 \\
Szociális intézményi feladatok & 49 & 28 \\
Szociális alapellátás & 145 & 84 \\
Gyermekvédelmi szakellátás & 3 & 1 \\
Gyermekjóléti alapellátás & 158 & 91 \\
Mozgókönyvtári feladatok & 112 & 65 \\
Belső ellenőrzés & 162 & 93 \\
Összesen & 173 & 100,0 \\
\hline
\end{tabular}

Forrás: Saját szerkesztés a BM honlapján elérhető adatokból.

http://www.bm.hu/web/portal.nsf/html/onkgazd.html/\$FILE/23_onkgazd.pdf?OpenElement 
A kistérségek számára juttatott normatív támogatások nagyságát és megoszlását mutatja a 4. táblázat 2009-ben. Eszerint a) a többcélú kistérségi társulásoknak kiutalt normatív támogatások több, mint felét, 51\%-át költötték a társulásban müködő közoktatási intézmények müködésének finanszírozására és a kistérségek által biztosított szakszolgáltatásokra; b) a szociális és gyermekjóléti szak- és alapszolgáltatások együttesen az összes támogatás negyedét szívták fel; c) általános költségekre $13 \%$ jutott; és d) a maradékon osztozott a mozgókönyvtári szolgáltatás és a belső ellenőrzés 7\%-kal, illetve 4\%-kal. Hozzátesszük, a közoktatásban felhasználható normatíva nagyrészt érintetlenül ,átutazik" a kistérségi társuláson, felhasználói a társult önkormányzatok által fenntartott intézmények.

\section{TÁBLÁZAT}

A TKT tevékenységeinek finanszírozása: a kistérségi normativa ágazati megoszlása a támogatott közszolgáltatások és régiók szerint, 2009 (\%)

(The Distribution of the Targeted Subsidies of Multifunctional Local Government Associations by the Type of Provisioned Services)

\begin{tabular}{|c|c|c|c|c|c|c|}
\hline Régió & Általános & Közoktatás & $\begin{array}{c}\text { Szociális } \\
\text { és gyer- } \\
\text { mek-jóléti } \\
\text { szolgálat }\end{array}$ & $\begin{array}{l}\text { Mozgó- } \\
\text { könyvtár }\end{array}$ & $\begin{array}{l}\text { Belsö } \\
\text { ellen- } \\
\text { örzés }\end{array}$ & Összesen \\
\hline Dél-Alföld & 14 & 43 & 37 & 2 & 3 & 100 \\
\hline Dél-Dunántúl & 10 & 56 & 23 & 8 & 3 & 100 \\
\hline Észak-Alföld & 13 & 47 & 34 & 2 & 4 & 100 \\
\hline $\begin{array}{l}\text { Észak- } \\
\text { Magyarország }\end{array}$ & 11 & 56 & 21 & 8 & 5 & 100 \\
\hline $\begin{array}{l}\text { Közép- } \\
\text { Dunántúl }\end{array}$ & 15 & 51 & 23 & 7 & 4 & 100 \\
\hline Pest megye & 20 & 35 & 38 & 2 & 5 & 100 \\
\hline $\begin{array}{l}\text { Nyugat- } \\
\text { Dunántúl }\end{array}$ & 14 & 51 & 17 & 14 & 5 & 100 \\
\hline Magyarország & 13 & 51 & 26 & 7 & 4 & 100 \\
\hline
\end{tabular}

Forrás: Saját szerkesztés a BM honlapján elérhető adatokból.

http://www.bm.hu/web/portal.nsf/html/onkgazd.html/\$FILE/23_onkgazd.pdf?OpenElement

A támogatott feladatok finanszírozásának regionális eltérései is említést érdemelnek: a Dél-Dunántúl és Észak-Magyarország közoktatása részesült a legnagyobb arányú támogatásban (56\%), s a Nyugat-dunántúli és Közép-dunántúli régióban is átlagos, azaz $51 \%$ volt a közoktatás részesedése a támogatásból (4. táblázat). Az általános költségekre költött támogatási összegekben is nagy eltérések voltak, majdnem kétszeres a különbség az erre a célra legkisebb (10\% - Dél-Dunántúl) és legnagyobb arányban költő régió (megye) között (20\% - Pest megye). Ezen eltérések mögött nem a kistérségi társulások preferenciái, hanem a támogatásokra való 
jogosultság eltérései húzódnak meg: az általános normatívát a népességszám és a településszerkezet határozta meg 2009-ben (és korábban is), a közoktatásra fordítható normatívát a társulásban fenntartott iskolák és a pedagógiai szakszolgáltatásokat igénybe vevők száma. Ráadásul az adatok vélhetően a jogosultságot és nem a végső felhasználást mutatják, néhány százalékpontos eltérés a ,jogosult” és a felhasznált összegek, illetve ezek arányai között nagyon is valószínü. ${ }^{9}$

\section{TÁBLÁZAT}

A támogatások, továbbá a gyermekek és a kistepelülési feladat-ellátási helyek megoszlása régiók szerint, 2009-ben

(The Distribution of Subsidies, Children and Schools of Villages with less than 1000 Inhabitants)

\begin{tabular}{|c|c|c|c|c|}
\hline Régiók & $\begin{array}{c}\text { Közoktatási } \\
\text { támogatások } \\
\text { 2009* }\end{array}$ & $\begin{array}{l}\text { Az összes } \\
\text { támogatás } \\
\text { 2009* }\end{array}$ & $\begin{array}{l}\text { 0-14 éves } \\
\text { gyerekek } \\
\text { megoszlása } \\
2008 * *\end{array}$ & $\begin{array}{c}\text { Az 500-999 } \\
\text { fös falvakban } \\
\text { müködö fel- } \\
\text { adat-ellátási } \\
\text { helyek } \\
\text { 2008*** }\end{array}$ \\
\hline & \multicolumn{4}{|c|}{ megoszlása (\%) } \\
\hline Dél-Alföld & 8,9 & 10,5 & 13,2 & 6,0 \\
\hline Dél-Dunántúl & 24,1 & 21,9 & 9,5 & 24,0 \\
\hline Észak-Alföld & 15,3 & 16,5 & 17,4 & 14,0 \\
\hline Észak-Magyarország & 20,6 & 18,7 & 13,5 & 24,0 \\
\hline Közép-Dunántúl & 13,2 & 13,2 & 11,0 & 12,0 \\
\hline Pest megye & 3,7 & 5,2 & 26,1 & 3,0 \\
\hline Nyugat-Dunántúl & 14,2 & 14,1 & 9,2 & 22,0 \\
\hline Összesen & 100,0 & 100,0 & 100,0 & 100,0 \\
\hline
\end{tabular}

Források:

* http://www.bm.hu/web/portal.nsf/html/onkgazd.html/\$FILE/18_2009_normativ.pdf?OpenElement;

** T-Star adatbázis;

*** KIR STAT adatbázis alapján (összeállította Bihari Zsuzsa, 2009. novemberi állapot).

Az 5. táblázat a kistérségi normatívák hároméves összesített adatai alapján azok regionális megoszlását szemlélteti. Eszerint a Dél-Dunántúl tekinthető az abszolút nyertesnek, amennyiben 2009-ben a kistérségeknek juttatott normatívákból a legmagasabb arányban részesült (22\%). Az ugyancsak aprófalvas Észak-magyarországi régió a második a rangsorban 19\%-os részesedéssel, ugyanakkor a legkevesebb Pest megyére jutott a többcélú kistérségi normatívákból (5\%-os részesedés). Ugyanez a rangsor mutatkozik a közoktatási támogatások megoszlását tekintve is, amin nincs mit csodálkozni, ha tudjuk, hogy az összes „kistérségi normatíva” több mint felét ez az ágazat kapja. Az 5. táblázat adatai közül még két információ érdemel 
figyelmet: egyrészről az, hogy a korábbi periódushoz képest kiegyenlítettebben oszlanak meg a források a régiók között, másrészt az, hogy a megoszlás nem a gyermekszám, hanem a kistelepüléseken még müködtetett feladat-ellátási helyek megoszlását követi (a leginkább). A nyugat-dunántúli az egyetlen aprófalvas régió, amelyik kevesebb támogatást szív fel, mint amennyi indokolt volna kistelepülési iskoláinak száma és aránya alapján. Egyelőre nem áll rendelkezésünkre olyan adatbázis, amely megbízható információval szolgálhatna a feladat-ellátási helyek függelmi és fenntartói viszonyairól, ez a TÁMOP 3.1.1. konstrukcióhoz kapcsolódó kutatás más szegmensében készül, s csak a későbbiekben lesz felhasználható. Feltételezésünk azonban az, hogy a Nyugat-Dunántúlon - a másik két aprófalvas régióhoz képest - aránylag több település lépett olyan menekülési ösvényre, amely nem jogosít többletnormatívára. Ilyen például az, amikor a korábban önkormányzati fenntartású iskola alapítványi vagy egyházi fenntartásba kerül (Váradi 2008b).

\section{A leginkább érintettek}

A közoktatási intézmények többlet támogatásával kapcsolatos kritériumok értelemszerủen az amúgy is létükért küzdő, nagyon rossz költséghatékonysági mutatókkal rendelkező egyiskolás kistelepüléseket vagy a több önkormányzat társulásában müködtetett kisiskolákat érintette elsősorban, amelyek nem tudták biztonsággal, több évre teljesíteni a létszámkritériumokat. A kisiskolák fenntarthatóságát megkérdőjelező és a kistérségi szintű, de legalábbis társulásban megvalósuló feladatellátást célzó ösztönzőknek nehéz volt (lett volna) ellenállni, mert a bezárással fenyegetett iskolákban folyó pedagógiai munka minősége és eredményessége éppúgy nem szerepelt a megmaradás vagy bezárás szempontjai között, mint a potenciális fogadó intézményeké. (Zárójelben hozzátesszük: a mérési eredmények 2008-ig nem voltak nyilvánosak ${ }^{10}$.) Az aprófalvas kistérségek adaptációját tovább nehezítette, hogy a kistérségi szint gyakran túl sok és nagyon más helyzetü település együttműködését követelte meg, különösen, de nem kizárólagosan nagyvárosok körül ${ }^{11}$. Ez a TKT konstrukció területi célzásának anomáliáira utal: míg az önálló fenntartásra képes, nagyobb lélekszámú falvak és városok által uralt kistérségekben csupán laza, szakmai együttműködések indokoltak a közoktatási intézmények között, addig az önálló intézményfenntartásra képtelen kistelepülések körében elkerülhetetlen a közös fenntartás. Ennek viszont nem a kistérség, hanem a mikro-térség, vagyis a településközi együttműködések által megrajzolt körzetek az adekvát területi szintjei. (Lásd erről a „Függőben” c. kötet tanulmányait, különösen: Hamar 2008; Kovács-Rácz 2008; Rácz 2008; Somlyódyné Pfeil 2008; Váradi 2008a; 2008b; és egy együttmüködési kudarcról beszámoló esettanulmányt: Kovács-Nagyrónai-Nyakó 2010.)

Az alábbi részfejezetek néhány, a kistérségi törvény által kiemelten érintett témakör kapcsán mutatják be a kistérségi törvény hatásait, miközben a többcélú kistérségi társulási konstrukció müködési mechanizmusainak egyikére-másikára is rávilágítanak. 


\section{A kisiskola szindróma és területi vonatkozásai}

Az intézmények megtartásáért folytatott küzdelem elsősorban a kistelepüléseken volt és maradt nehéz, különösen az elöregedéssel, elnéptelenedéssel küszködő aprófalvas vidékeken. Ezek közül a Nyugat-dunántúlii régióban találjuk a legnagyobb, összefüggő területeket, ezért 2005-ben itt volt a legtöbb olyan iskola, amelynek tanuló létszáma nem éri el a száz főt. A többi aprófalvas régióban a kiüresedő és a roma népesség magas aránya következtében fiatalodó települések rendszerint mozaikszerüen helyezkednek el.

\section{5. ÁBRA}

Tanulólétszám az iskolafenntartó településeken 2005-ben (The Number of Students by Local Communities)

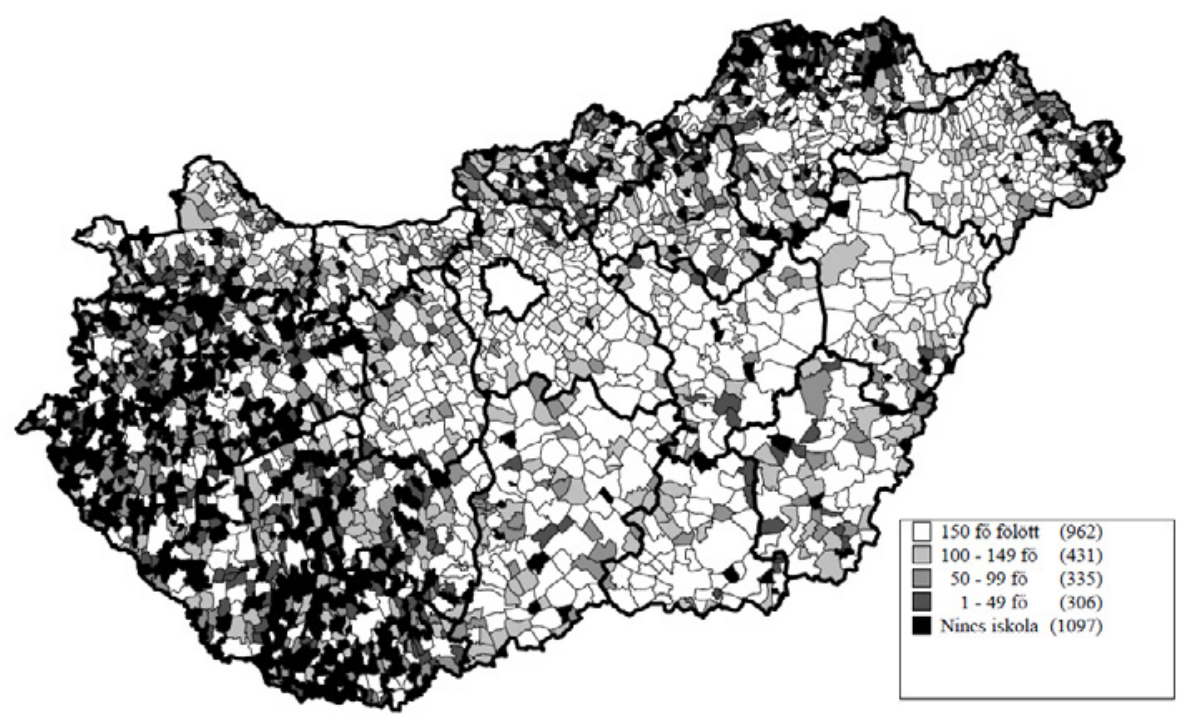

Forrás: Győri kötet. A térképet Koós Bálint készítette.

A kistelepülések kisiskoláinak ügye 2004-2005-ben - érdekes módon nem a TKT konstrukcióhoz kapcsolódóan, de - újra megjelent a kutatásokban és a szakmapolitikai diskurzusokban (összegző jelleggel: Radó 2006), nagyjában-egészében a korábbiakhoz hasonló következtetésekkel. Az elemzések kimutatták, hogy a kisméretü (100 fő alatti) iskolák fajlagosan kétségtelenül drágábbak, sőt, a nagyon kicsi iskolák extrém módon drágák, ám csak a helyi költségvetéshez mérten, mert oly kevés gyermek tanul ezekben az iskolákban, hogy finanszírozásuk részaránya otszágos szinten, a közoktatás éves költségeinek csupán néhány százalékát igényli (Horn 2004; Hermann 2005). Horn azt is kiszámolta, hogy mekkora megtakarítást jelentene, ha az összes 100 fö alatti iskolát bezárnák, és 150 vagy 200 főben határoznák meg az iskolafenntartási létszámküszöböt. Az eredmény a következő: a 100 tanulónál kevesebb gyereket oktató iskolák bezárásával a falvak oktatási kiadásainak 4,25\%-át, az összes önkormányzati oktatási kiadás 0,95\%-át lehetne megtakarítani, s ha az iskola- 
méret alsó határát 150 tanulóban állapítanánk meg, a megtakarítás az alapszintü oktatásra fordított országos kiadások 2,2\%-ára rúgna.

Hermann felhívta a figyelmet a támogatáspolitika ellentmondásosságára, hogy t.i. az intézményfenntartó társulások megalakulását ösztönözte, ám ezzel egy időben az iskolákat fenntartó kistelepüléseket is támogatta (Hermann 2004a; 2004b). Hermann arra is rámutatott, hogy a kisiskolák helyi társadalmakban játszott szerepe következtében a fenntartók nem eléggé érdekeltek a hatékonysági szempontok érvényesítésében, s csak akkor zárják be iskolájukat, ha annak további müködtetése csőddel fenyegetne. Vagyis nem hajlandók megfizetni azt a ,politikai költséget”, amit a megtakarításért cserébe kellene fizetniük. Ezért, mint mondja „csak olyan kormányzati programok jelenthetnek megoldást, melyek ... egyúttal a politikai költségek jelentös részét is magára vállalják" (Hermann 2004a). Kijelenthetjük, hogy azt a trójai falovat, amely az intézményi centralizáció politikai költségét magára vállaló kormányzati politikát hordozta, többcélú kistérségi társulásnak hívják.

Eltekintve a bonyolult kvóta-rendszer ismertetésétől, csak azt jegyezzük meg, hogy a párhuzamos osztályok nélküli nyolcosztályos nyolcosztályos iskolákat fenntartó, a többcélú kistérségi társuláshoz csatlakozó önkormányzatoknak három éven belül 123 fős létszámot kellett vállalniuk úgy, hogy a 7. és 8. osztályban a tanulólétszámnak el kellett érnie a 15 föt. A kistelepülési környezetben ajánlott, egyébként a fő politikai erők egyetértését élvező iskolaszervezési és fenntartási képlet szerint az óvoda mellett az alsó tagozat, legfeljebb az 1-6 osztály helyben maradhat, ám a felső tagozatnak, de legalább a 7. és 8. osztálynak nagyméretü, jól felszerelt oktatási intézményekben a helye, amelyek versenyképes tudással vértezik fel a tanulókat. Nos, nem is volna semmi baj, ha az ország településszerkezete ezt könnyedén megvalósíthatóvá tenné, ám nem így áll a helyzet. A 6. táblázat a 150 fős tanulólétszámnál kisebb iskolák megoszlását mutatja méretkategóriák és azok jellemzői szerint, a táblázatot követő térkép (6. ábra) pedig az ország kistérségeit mutatja aszerint, hogy ez az iskolatípus (a 150 tanulónál kevesebb tanulót, átlagosan 125 föt befogadó, párhuzamos osztályok nélkül müködő iskola) milyen arányt képvisel a kistérség iskolái között.

\section{TÁBLÁZAT}

A 150 fösnél kisebb tanuló létszámú iskolák jellemzői 2006-ban (The Features of Small Schools with less than 150 Students in 2006)

\begin{tabular}{|c|c|c|c|}
\hline Alapadatok/kisiskola-kategóriák & $5-49 f^{\prime \prime}$ & $50-99 f^{\prime \prime}$ & $100-149 f^{\prime \prime}$ \\
\hline Iskolák száma (db) & 301 & 315 & 410 \\
\hline Összesen $(d b)$ & & 1026 & \\
\hline Az egy iskolára jutó osztályok száma (db) & 2 & 7 & 8 \\
\hline A tanulók átlagos száma (fö) & 24 & 78 & 125 \\
\hline A tanulók száma (fö) & 7173 & 24556 & 51173 \\
\hline Összes tanuló (fö) & & 82902 & \\
\hline Pedagógusok száma (fő) & 1073 & 3304 & 5750 \\
\hline Összes pedagógus (fö) & & 10127 & \\
\hline Egy pedagógusra jutó tanuló (fö) & 7 & 7 & 9 \\
\hline
\end{tabular}

Forrás: Győri kötet. A Koós Bálint által összeállított adatbázisból szerkesztette Kovács Katalin. 


\section{6. ÁBRA}

A 150 fösnél kisebb iskolák aránya a kistérségek összes iskoláinak \%-ában, 2005 (The Rate of Schools with Less than 150 Students in the \% of the Total Number of Schools by Micro-Regions)

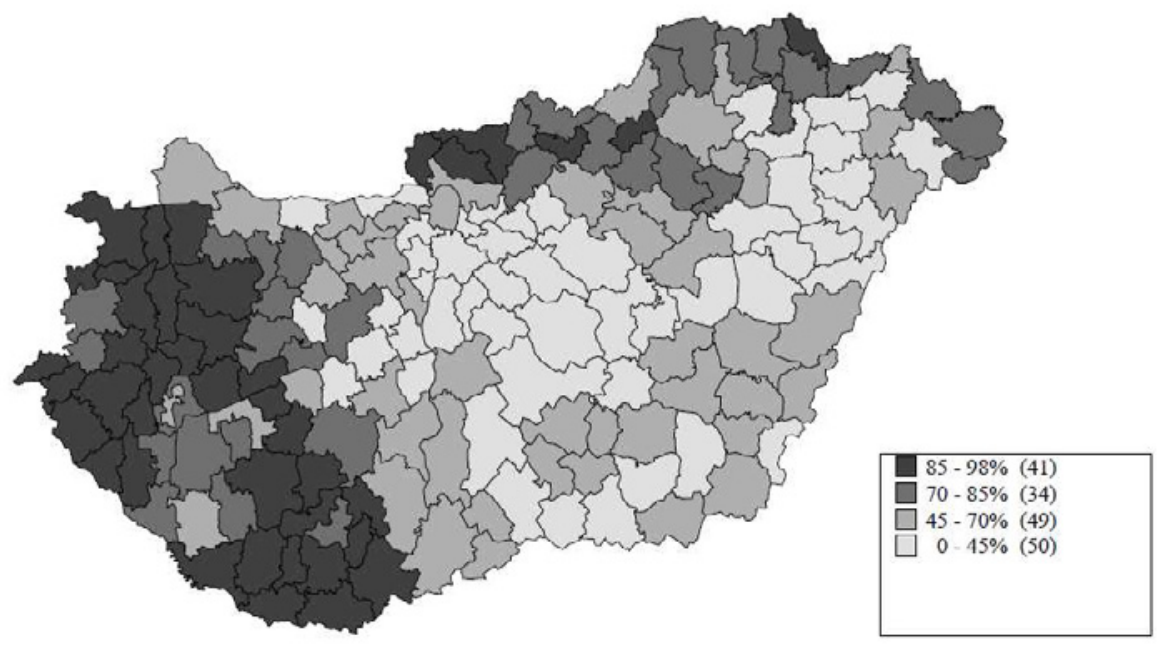

Forrás: Győri kötet. A térképet Koós Bálint készítette.

A 6. táblázat a probléma nagyságrendjét hivatott érzékeltetni, a térkép (6. ábra) azokat a vidékeket mutatja, ahol majdnem az összes iskola érintett a 2004 óta zajló átalakulásban. 2006-ban a települések 35\%-a, értelemszerüen kisközségek, már nem üzemeltetett általános iskolát (ez akkor 1104 települést jelentett). 1766 iskola ún. egyiskolás településen működött, ami a települések 56\%-át, az iskolák 49\%-át jelentette. A táblázatban szereplő 1026 „kisiskola” - a 2006-ban működő általános iskolák 29\%-a - túlnyomórészt ezek közül került ki. Nagyon valószínü, hogy ez az a kategória, amelynek mintegy fele elvérzett, legalábbis önálló fenntartású intézményként, azt pedig a hivatkozott kutatásnak kell kiderítenie, hogy mi maradt a megszünt iskolák nyomában.

A közölt térképek jól érzékeltetik az ország régióinak, kistérségeinek eltérő érintettségét. Az elvérző iskolák túlnyomó többsége a Dunántúlon, kisebb része ÉszakMagyarországon, és elszórva az ország foltokban elhelyezkedő aprófalvas / kistelepülések által uralt vidékein helyezkedett el. A védekezés, az intézmények megőrzésének kétségbeesett küzdelme nagyon jelentős helyi és településközi energiákat mozgatott meg, amelyről szociografikus leírásokat és elemzéseket egyaránt olvashatunk Váradi Monika Mária tollából (Váradi 2008a; 2008b) és a Függőben c. tanulmánykötet más esetleírásaiból (Kovács-Somlyódyné Pfeil 2008).

Újra fel kell hívnunk a figyelmet arra, hogy nemcsak a kistérségi törvény felelős az alapfokú oktatás intézményrendszerének ilyen mértékủ átalakításában, hanem az ÖNHIKI jogosultsági kritériumok ${ }^{12}$ is. Emellett a Regionális Operatív Programok, 
különösen a Dél-dunántúli régió Regionális Operatív Programja jeleskedett az intézményi koncentráció ösztönzésében. A dél-dunántúli döntéshozók ${ }^{13}$ fejlesztési filozófiája, amely egybeesett a kormányzati politikát támogató szakmai körök álláspontjával, a központi és regionális fejlesztéspolitika konfliktusmentes összekapcsolását tette lehetővé. A dél-dunántúli eredmény: a községi fenntartású iskolák majdnem $70 \%$-os csökkenése öt éven belül.

\section{Első és másodrendü társulások}

Mint erre korábban utaltunk, a többcélú kistérségi társulások által fenntartott intézményeket mintegy 20\%-kal több normatíva illeti meg, mint azokat, amelyeket az 1997-es társulási törvény szerint együttmüködő önkormányzatok üzemeltetnek. Ha az ösztönzö(k) hatására a fenntartók iskoláik tömeges átadása mellett döntenek (döntöttek volna), akkor ez alapjaiban kérdőjelezte volna meg az érvényben lévő önkormányzati rendszert. Ez azonban - öt év tapasztalatai alapján kijelenthetjük nem következett be; bár nagy horderejü változásokat regisztrálhatunk, s a többcélú kistérségi társulások fenntartói funkciókat is ellátnak, a szervezeti változások túlnyomórészt a korábbi nyomvonalakon haladtak, vagyis a lépéskényszerbe kerülö önkormányzatok túlnyomó többsége továbbra is a szabad intézményi társulási formák adta lehetöségekkel élt.

Intézményfenntartó társulások értelemszerüen az aprófalvas területeken jöttek létre legnagyobb számban már 1997 elött is, a társulási törvény és az ösztönző normatívák megjelenése után azonban gyorsan gyarapodó számban (3-4 év alatt 20\%-kal nőtt a társulások száma - lásd Imre 2003). Érdekes módon, a Dunántúlon és ÉszakMagyarországon eltérő társulási formák alakultak ki. A Dunántúlon főleg intézményfenntartó társulások, az Észak-magyarországi régióban „közoktatási feladatellátó társulások" müködtek: egy 2001/2002-es tanévben folytatott vizsgálat szerint a Nyugat-Dunántúlon volt a legnagyobb a társulási hajlandóság az aprófalvas vidékek közül (a mintába került települések ${ }^{14}$ 69\%-a intézményi társulásban tartotta fenn az általános iskoláját ${ }^{15}$ ), ezt követte a Dél-Dunántúl 53\%-kal, majd a KözépDunántúl és Észak-Magyarország következett 31 és 29\%-kal. Az önálló intézményfenntartásra képes települések által uralt Dél-Alföldön és Pest megyében nem érte el a társult települések aránya az 5\%-ot, míg az Észak-Alföldön viszonylag számottevő arányt, 15\%-ot képviseltek az intézményfenntartó társulásban részt vevő települések, föként az 500-1000 fős kategóriában.

A kistérségi közoktatási feladatellátó társulások, amelyek a TKT konstrukció előtt Borsod-Abaúj-Zemplén megyében müködtek kitünő hatékonysággal, mindazokat az együttmüködési formákat felvonultatták (igazgatói munkaközösségek müködtetése, szervezett információcsere, közös képzések, versenyek, tehetséggondozás, hátránykompenzálás stb.), amelyeket más vidékeken a többcélú kistérségi társulások hívtak elő (Lukács 2004). Söt, egy önértékelési csomagot is kifejlesztettek, amely a korábbiak mérlegelése mellett a közös munka továbbfejlesztésére is készen 
állt (Setényi 2004). Hasonló kezdeményezések másutt is működtek, ám kevésbé összehangolt formában, ezért kevesebb eredményt tudtak felmutatni.

Mindenesetre tény, hogy ahol intézményfenntartó társulások már korábban is müködtek, a megalakuló kistérségek gyorsabban jutottak többlettámogatáshoz, hiszen ez a társulási forma mindvégig jogosult maradt többlet támogatásra, csak éppen kevesebbre, mint a kistérségi társulások által fenntartott intézmények ${ }^{16}$. Arról nincs tudomásunk, hogy hány egységes iskola müködik Magyarországon, vélhetően nagyon kevés, arról azonban igen, hogy miként alakult 2009-re a társulási törvény alapján alakult intézményfenntartó társulások és a többcélú kistérségi társulások által fenntartott intézmények száma, amelyet a 8. táblázat szemléltet.

\section{TÁBLÁZAT}

Társulási típusok és társulási fenntartású közoktatási intézmények, 2009 (The Types of Local Government Associations and their Institutions Maintained)

Többcélú kistérségi társulás által fenntartott intézmények

\begin{tabular}{lcc}
\hline Intézmények típusa & Fenntartók száma & Intézmények száma \\
\hline Óvoda & 26 & 41 \\
Általános iskola & 32 & 47 \\
Középfokú intézmények & 9 & 10 \\
Kollégium & 7 & 7 \\
$\begin{array}{l}\text { Alapfokú múvészetoktatási } \\
\text { intézmények }\end{array}$ & 17 & 19 \\
Összesen & 91 & 124 \\
\hline \multicolumn{1}{c}{ Intézményi társulások által fenntartott intézmények } \\
\hline $\begin{array}{l}\text { Óvoda } \\
\text { Általános iskola }\end{array}$ & 456 & 464 \\
Középfokú intézmények & 448 & 459 \\
Kollégium & 30 & 31 \\
Alapfokú mủvészetoktatási & 21 & 21 \\
intézmények & 107 & 107 \\
Összesen & 1062 & 1082 \\
$\begin{array}{l}\text { Többcélú és intézményfenntartó } \\
\text { társulások együtt }\end{array}$ & 1153 & 1206 \\
\hline
\end{tabular}

Forrás: Dienes (2009).

A 7. táblázat kétséget kizáróan mutatja, hogy a jelentős (20-30\%-os) mértékü többlet normatíva dacára csak viszonylag kevesen szánták el magukat arra, hogy kistérségi fenntartásba adják közoktatási intézményeiket. Azok az önkormányzatok, amelyeknek fel kellett adniuk az önálló intézmény-fenntartást, inkább választották 
a társulási törvény alapján kínálkozó, a partnerségnek nagyobb teret engedő intézményi társulási formát, mint a TKT fenntartást. Arról, hogy a TKT fenntartású közoktatás olcsóbb-e és ha igen, mennyivel, nem születtek tanulmányok; ennek tisztázása is egyik célja az empirikus kutatásnak. Az MTA RKK Térségfejlesztési Kutatások Osztályán folytatott korábbi kutatásaink alapján úgy láttuk, hogy a TKT fenntartás mellett voksoló önkormányzatok szorultságukban határoztak így, és döntésük hátterében főként a közoktatásra fordítható külső források maximalizálásának törekvése állt. Ugyanakkor - paradox módon - arra is volt példa, hogy a TKT fenntartás éppen a meglévő, széttöredezett struktúrákat konzerválta és az együttműködési alkalmatlanságot takarta/legitimálta (Hamar 2008).

A kistérségi törvény szerkezet-átalakító ereje elsősorban „intézményritkító” hatásában érhető tetten, s annak mértékéröl is nagyjából megegyeznek a becslések, számítások. Az ÁSZ-jelentés és Imre Anna is úgy találta, hogy a fenntartók száma 40\%-ot meghaladó mértékben csökkent (ÁSZ 2008; Imre 2009), ám ez a legtöbb esetben nem az alapfokú intézmények megszüntetését, hanem intézményösszevonásokat jelentett, az alsó tagozat tehát sok helyen megmaradt, csak éppen egy közeli, központi iskola részeként. Ezt valószínüsíti Balázs Éva kutatása is (Balázs 2009). Hogy nemcsak intézmény-összevonásokra, hanem bezárásokra is sor került, azt a feladatellátó helyek számának csökkenése mutatja (óvodák esetében 5\%-kal, iskolák esetében 9\%-kal).

\section{7. ÁBRA}

A feladatellátó helyek fenntartói körének változása, 2008/2004 (\%)

(Changes amongst the Ranks of Bodies Engaged in Maintaining Schools)

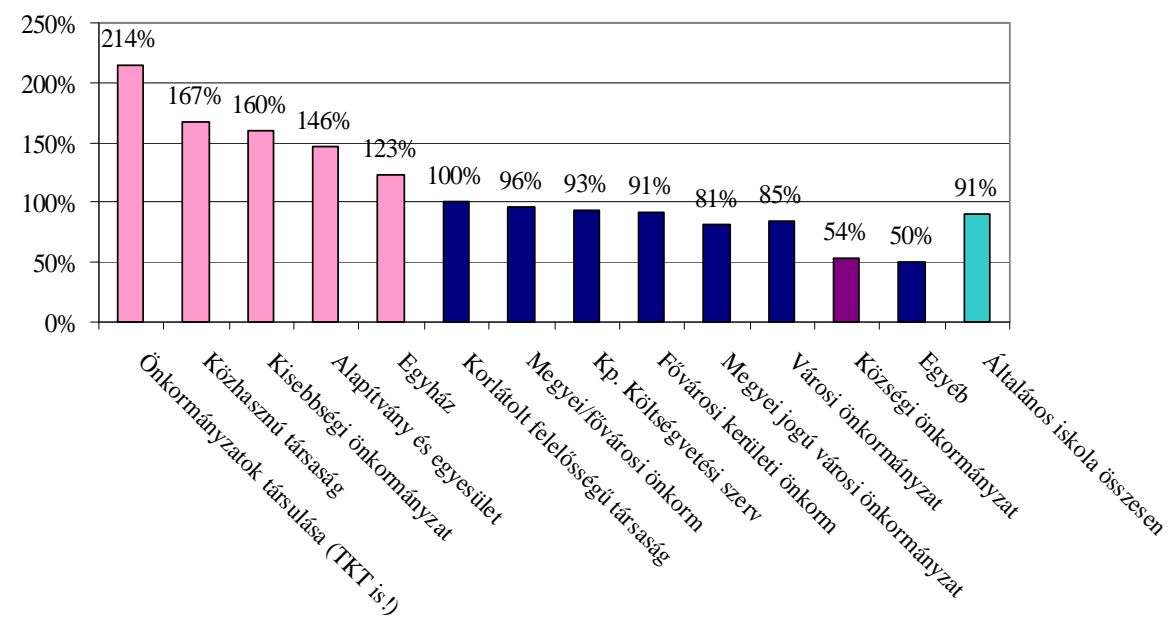

Forrás: Saját szerkesztés a Bihari Zsuzsa által a KIRS TAT alapján összeállított adatbázisból (2009. novemberi adatállomány). 
A KIR STAT alapján készült adatbázis elemzésének egyik eredményét mutatja az elözö ábra, amely alapján megerösíthető: a társulásban fenntartott iskolák száma és aránya megduplázódott 2004 és 2008 között. A grafikon jól szemlélteti a fenntartói változtatásokban megnyilvánuló menekülési ösvények sokféleségét, az egyházak, alapítványok és kisebbségi önkormányzatok megnövekedett szerepét. Hozzátesszük: a kiútkeresésnek, kivárásnak több eszközével éltek és élnek az önkormányzatok, köztük olyanok is, amelyek végül a fenntartás feladására kényszerültek. Ilyen a nemzetiségi (etnikai) nevelés bevezetése, amely jelentős többlet-támogatást biztosít(ott). Eme közkeletű települési stratégia eredményeként 2004 és 2009 között bő háromszorosára, 340 millió forintról 1100 millió forintra nőtt a nemzetiségi oktatás támogatása címén felhasznált költségvetési forrás ${ }^{17}$. A nemzetiségi (etnikai) oktatás jelentősége azonban nem csak a többlet-forrás biztosításában mutatkozik meg, hanem abban és a kistelepülések számára talán elsősorban abban, hogy legalizálja / legalizálta az alacsony (óvodai) csoport- és (iskolai) osztálylétszámokat. Az iskolai feladat-ellátó helyek fenntartásában bekövetkezett átrendeződést mutatja a 8 . táblázat.

\section{TÁBLÁZAT}

A fenntartók átrendezödése: iskolai feladat-ellátó helyek, 2004-2008 (\%)

(The Rearrangement within the Ranks of School Maintaining Entities by Regions, 2004-2008)

\begin{tabular}{cccccccc}
\hline Fenntartók & $\begin{array}{c}\text { Dél- } \\
\text { Alföld }\end{array}$ & $\begin{array}{c}\text { Dél- } \\
\text { Dunán- } \\
\text { túl }\end{array}$ & $\begin{array}{c}\text { Észak- } \\
\text { Alföld }\end{array}$ & $\begin{array}{c}\text { Észak- } \\
\text { gyar- } \\
\text { ország }\end{array}$ & $\begin{array}{c}\text { Közép- } \\
\text { Dunán- } \\
\text { túl }\end{array}$ & $\begin{array}{c}\text { Közép- } \\
\text { Ma- } \\
\text { gyar- } \\
\text { ország }\end{array}$ & $\begin{array}{c}\text { Nyugat- } \\
\text { Dunán- } \\
\text { túl }\end{array}$ \\
\hline $\begin{array}{c}\text { Községi önkor- } \\
\text { mányzatok }\end{array}$ & 49 & 35 & 64 & 54 & 51 & 71 & 49 \\
\hline $\begin{array}{c}\text { Városi önkor- } \\
\text { mányzatok }\end{array}$ & 66 & 88 & 99 & 68 & 97 & 105 & 60 \\
\hline $\begin{array}{c}\text { Megyei jogú városi } \\
\text { önkormányzat/ } \\
\text { fóvárosi és kerületi } \\
\text { önkormányzatok }\end{array}$ & 74 & 57 & 86 & 72 & 85 & 92 & 92 \\
\hline $\begin{array}{c}\text { Megyei önkor- } \\
\text { mányzatok }\end{array}$ & 100 & 87 & 100 & 94 & 108 & 100 & 93 \\
\hline $\begin{array}{c}\text { Alapítványok, } \\
\text { egyesületek }\end{array}$ & 140 & 120 & 120 & 167 & 100 & 117 & 467 \\
\hline $\begin{array}{c}\text { Egyházi jogi } \\
\text { személyek }\end{array}$ & 115 & 120 & 119 & 122 & 143 & 120 & 120 \\
\hline $\begin{array}{c}\text { Önkormányzati } \\
\text { intézmény- }\end{array}$ & 482 & 132 & 308 & 260 & 180 & 222 & 107 \\
\hline \begin{tabular}{c} 
fenntartó társulások \\
\hline Egyéb
\end{tabular} & 110 & 83 & 100 & 133 & 150 & 150 & 80 \\
\hline $\begin{array}{c}\text { Összesen } \\
84\end{array}$ & 86 & 92 & 88 & 93 & 97 & 86 \\
\hline
\end{tabular}

Forrás: Saját szerkesztés a Bihari Zsuzsa által a KIRS TAT alapján összeállított adatbázisból (2009. novemberi adatállomány). 
A 8. táblázat adatai a régiók eltérö érintettségét viszonylag pontosan szemléltetik. Az önálló iskola-fenntartás a Dél-Dunántúlon szorult a leginkább vissza, amibe a régió fejlesztéspolitikai elképzelései is nagy szerepet játszottak: a Dél-dunántúli Regionális Operatív Program elsősorban a legalább 300 tanulónak helyet adó, ún. integrált intézmények fejlesztéseit támogatta. Ebben a régióban a 164 községi feladatellátási hely 65\%-a (106 db) szünt meg 2004 és 2008 között. Észak-Magyarország községeiben 154 feladatellátó hellyel volt kevesebb 2008-ban, mint 2004-ben, ez azonban „csak” 49\%-os csökkenést jelent. Ebben a régióban 121-gyel nőtt az önkormányzati társulásban fenntartott feladat-ellátási helyek száma, míg a Dél-Dunántúlon csak 47-tel. Ugyanitt 28 község döntött a TKT fenntartás mellett, miközben 30 és 40 közöttire tehető a megszünt feladat-ellátási helyek száma. Ennél többre becsülhető a Nyugat-dunántúli régióban megszűnt iskolák száma, nem véletlenül, hiszen itt található a legtöbb kiüresedő település és itt müködött a legtöbb kisiskola. Itt csak nyolccal nőtt az önkormányzati társulásban fenntartott feladat-ellátási helyek száma és 22 község iskoláját müködteti a többcélú kistérségi társulás. Itt menekült azonban a legtöbb önkormányzat (22 település) az alapítványi fenntartás felé.

\section{Összegzés}

Az, hogy a községi fenntartásban lévő iskolák száma majdnem felére csökkent mindössze négy év leforgása alatt, az a kistelepülési önkormányzatok önálló intézményfenntartói képességének tömeges ellehetetlenüléséről vall. Ebben az elöre haladott demográfiai erózió, a tovább csökkenő gyermekszám mellett a változásokat kikényszerítő rendelkezések vitatható elemei is szerepet játszottak, így az, hogy tekintet nélkül a településszerkezeti sajátosságokra egységes létszámkövetelményeket támasztottak, vagy az, hogy a kistérségi szint kivételes preferenciákat, többlettámogatást kapott. Ezek az intézkedések különösen az aprófalvas övezetek intézményfenntartóit sújtották. Az önálló intézményfenntartás tömeges feladása mögött azonban mégsem ez, hanem a forráshiány állt, ez szorította a kistelepülési önkormányzatok mintegy felét arra, hogy iskoláik bezárása vagy tagiskolaként való működtetése mellett döntsenek. Volt, ahol ez elkerülhetetlen, szükségszerü lépést jelentett, amelyet csak előre hoztak az ösztönző rendelkezések, de olyan esetekröl is tudunk, ahol a kisiskolákat aránytalanul sújtó, 2007-től bevezetett finanszírozási prés mellett a regionális fejlesztéspolitika kényszerítette ki az intézmény-összevonást.

A lépéskényszerben adott válasz, a kistelepülési intézményfenntartók egyre több települést tömörítő társulásba kényszerülése bár gyakorta elkerülhetetlen, mégis aggodalmakat ébreszt. Nagy kérdés, hogy az összevonások / intézmény-bezárások milyen közvetett hatásokat váltanak ki a helyi közösségekben, elsősorban a Dunántúlon, ahol becslésünk szerint körülbelül ugyanannyi iskolát zártak be, mint amennyi társulási fenntartásba került. Vajon nem vált-e ki újabb elvándorlási hullámot, nem jelent-e kegyelemdöfést az érintett kistelepülések számára intézményük bezárása? Vajon tartósan fenntarthatók maradnak-e a tagiskolává vált kisiskolák vagy csak néhány év haladékot kaptak? 
Bár a szerző meggyőződése szerint a kistelepülések világában nincs alternatívája a közös intézményfenntartásnak, a rendszerint előkészítetlenül és túl nagy területre kiterjedő iskolakörzetek kikényszerítését szükségtelennek tartja, amely az arányos és fenntartható együttműködések kialakulásának ellenében hat. Ezért azt reméli, hogy az elkövetkező évek a mérsékelt korrekció, a türelmes és racionális intézményszervezés évei lesznek a közoktatásban, amelyek - az együttmüködések ösztönzését megtartva - visszahozzák a társulási formák egyenjogúságát és egy differenciált követelményrendszert állítanak fel a különböző településszerkezetü vidékek intézményfenntartói számára.

\section{Jegyzetek}

${ }^{1}$ A szerző ezúton fejezi ki köszönetét Balázs Évának és Váradi Monika Máriának azokért az értékes megjegyzésekért, amelyeket a tanulmány első változatához füztek, továbbá Koós Bálintnak a Győri Kötet adatai alapján elkészített térképekért.

${ }^{2}$ Az Oktatáskutató és Fejlesztő Intézet által koordinált, TÁMOP 3.1.1./7.3 . számú, „A 21. századi közoktatás - fejlesztés, koordináció” c. projekt. Témavezető: Balázs Éva.

3 1997. évi CXXXV. Törvény a helyi önkormányzatok társulásairól és együttműködéséről.

4 2004. évi CVII. Törvény a települési önkormányzatok többcélú kistérségi társulásáról.

${ }^{5}$ Egy-egy közszolgáltatásra ajánlott többféle társulási forma.

${ }^{6}$ Sajnos a használt forrás nem teszi lehetővé az alapfokú és középfokú oktatási kiadások elkülönítését a 2000. és 2003. évekre.

7 Részleges megalakulás esetén vagy a települések, vagy a népességszám esetében kellett a 60\%-os többletet igazolni, ami egyfajta fokozatosságot tett lehetővé kistérségeken belül is. 2006-tól megszűnt a társulások ilyen szempont szerinti nyilvántartása, ami vélhetően azt jelenti, hogy maga a jelenség is megszünt: nemcsak a társulások száma gyarapodott, hanem a korábban nem társult települések is csatlakoztak. Erre utal a 2008-as ÁSZ jelentés, mely szerint a közös feladatellátásban részt vevő települési önkormányzatok száma 122\%-os emelkedéssel rögzült 2006-ban (ÁSZ 2008, Összegző táblázatok).

8 Ezek zömmel, de nem kizárólag, 2007-2008-ban alakult kistérségi társulások: a debreceni, gödöllői, dunakeszi, érdi, kunszentmártoni, bácsalmási, sárospataki, mezőkovácsházi.

${ }^{9}$ Például kutatási terepeink közül a Sásdi kistérség a pedagógiai szakszolgáltatásokra a kapott normatíván felül is kénytelen volt költeni a 2006/2007-es tanévben: évi bő hárommillió forinttal kellett kiegészíteni azt, ami ,járt”, és ezt inkább az ,általános” normatíva terhére tették meg, mintsem, hogy összeadják a települési önkormányzatok.

${ }^{10}$ Ugyanakkor azt is meg kell említenünk, hogy ha az eredményességi mutatók rendelkezésre álltak volna, azok kiterjedt aprófalvas övezetekben végtelenül gyenge tanulói teljesítményeket mutattak volna, éspedig azokban a falvakban, ahol a gettósodás nagymértékben elörehaladt, tehát a tanulók többsége halmozottan hátrányos helyzetű, roma családokból érkezik. Ez nem zárja ki a magas pedagógiai hozzáadott értéket!

${ }^{11}$ Lásd azt a szakadékszerű különbséget, amely például a Zalaegerszeget, Kaposvárt, Pécset, Miskolcot övező kistérségek városkörnyéki, belső övezetei és a széleken elhelyezkedő kistelepülések között feszülnek.

${ }^{12}$ Ettől az évtől, felmenő rendszerben, 50\%-ról 70, illetve 75\%-ra kellett felvinni az iskolai osztályok létszámadatait a közoktatási törvényben elöírt maximális osztálylétszámokhoz képest.

${ }^{13}$ A keretet az ún. Humán-erőforrásfejlesztési Stratégiai Program jelentette, melyet az ügynökség megrendelésére egy tanácsadó cég készítette, s amelyet a regionális fejlesztési tanács elfogadott.

14162 település képezte a mintát, ebből 140 település 2000 fó alatti.

15 A mintába került nyugat-dunántúli települések közül az 500 fösnél kisebbek valamennyien, az 500 és 1000 fő közötti lakónépességgel rendelkező falvak 83\%-a volt tagja általános iskolát fenntartó társulásnak. 
${ }^{16}$ További kitüntetett kategória a középiskolák közül az egységes iskolák részeként működő 9-13. évfolyamok.

${ }^{17}$ Forrás: az adott évre vonatkozó zárszámadási törvények 4. melléklete. http://www1.pm.gov.hu

\section{Irodalom}

ÁSZ (2008) 0817. sz. Jelentés a települési önkormányzatok többcélú kistérségi társulásainak a közszolgáltatások és a területfejlesztési feladatok ellátásában betöltött szerepének ellenörzéséröl. Állami Számvevőszék, Budapest. 2008. július. http://www.asz.hu/ASZ/www.nsf/jelentesek.html

Balázs É. (2008) Stratégiától a kistérségi együttmüködésekig. Az idegennyelv oktatás koordinációja. http://ofi.hu/tudastar/fokuszban-nyelvtanulas/balazs-eva-strategiatol

Balázs É. (2009) Kistérségi közoktatás. Tények és vélemények egy kérdöíves vizsgálatból. http://ofi.hu/rendezvenyek/kistersegek-utkozben

Deli E.-Gurnik Ágnes-Varga Sándor (2004) A társulás költségvetése, gazdálkodása, vagyona. Kistérségek Kézikönyve. Szakértői módszertan és dokumentumtár. Budapest, Magyar Közigazgatási Intézet.

Dienes R. (2009) A többcélú kistérségi társulások közoktatási feladatellátásának elmúlt 6 éve. http://ofi.hu/rendezvenyek/kistersegek-utkozben

Education at a glance 2009. OECD indicators. (2009) OECD, Paris.

eKözig (2008) A többcélú kistérségi társulások müködési tapasztalatai 2004-2008. eKözig Regionális Informatikai Szolgáltató Központ Zrt., Budapest.

Hamar A. (2008) Együttmüködésre kényszerítve. - Kovács K. -Somlyódyné Pfeil E. (szerk.) Függőben. Közszolgáltatás-szervezés a kistelepülések világában. CompLex Kiadó Kft., Budapest. 371-406. o.

Havas G. (2008) Esélyegyenlőség, deszegregáció. - Fazekas K.-Köllő J.-Varga J. (szerk.) Zöld könyv a magyar közoktatás megújításáért 2008. Ecostat, Budapest. 121-138. o.

Hermann Z. (2004a) A demográfiai változás hatása az iskolai ráfordításokra. http://ofi.hu/tudastar/hatekonysagi-problemak/demografiai-valtozas

Hermann Z. (2004b) A helyi és a központi szint felelösség-megoszlása a hatékonyság javítása területén. http://ofi.hu/tudastar/onkormanyzat-kozoktatas/hermann-zoltan-helyi

Hermann Z. (2005) A falusi kisiskolák és a mérethatékonysággal összefüggö hatékonyságveszteségek. http://ofi.hu/tudastar/hatekonysagi-problemak/falusi-kisiskolak

Horn D. (2004) Mennyibe kerül egy gyerek? Az általános iskolák oktatási szolgáltatásainak költségbecslése. Önkormányzati oktatáspolitika és oktatásfinanszírozás. Országos Közoktatási Intézet, Budapest. 5-18. o.

Horn D. (2005) A kistelepülések kisiskolái - társulás. http://ofi.hu/tudastar/onkormanyzatkozoktatas/kistelepulesek

Imre A. (2003) Oktatási feladat-ellátást segítő önkormányzati társulások. - Magyar Pedagógia. 3. 371-387. o.

Imre A. (2009) Az általános iskolai intézményhálózat változásai - a kisebbségi oktatás szerepének növekedése. - Új Pedagógiai Szemle. Április. 85-96. o.

Kertesi G. (2008) A közoktatási intézmények teljesítményének mérése-értékelése, az iskolák elszámoltathatósága. - Fazekas K.-Köllő J.-Varga J. (szerk.) Zöld könyv a magyar közoktatás megújításáért 2008. Ecostat, Budapest. 167-189. o.

Kovács K. (2009) Területi társadalmi problémák és a célterületi lehatárolás kérdései. Kézirat. MTA RKK, Budapest.

Kovács K.-Nagyrónai J.-Nyakó M. (2010) Egy (kis-)iskolatörténet és tanulságai. - Lányi A.-Farkas G. (szerk.) Miért fenntarthatatlan, ami fenntartható? L' Harmattan, Budapest. 62-100. o.

Kovács K.-Rácz K. (2008) Mozgásban: az együttmüködés változó mintázatai a Sásdi Többcélú Kistérségi Társulásban. - Kovács K.-Somlyódyné Pfeil E. (szerk.) Függőben. Közszolgáltatás-szervezés a kistelepülések világában. CompLex Kiadó Kft., Budapest. 281-304. o.

Kovács K.-Somlyógyné Pfeil E. (szerk.) (2008) Függöben. Közszolgáltatás-szervezés a kistelepülések világában. CompLex Kiadó Kft., Budapest.

Köllő J. (2009) A pálya szélén. Iskolázatlan munkanélküliek a posztszocialista gazdaságban. Osiris, Budapest.

Ladányi J.-Szelényi I. (2005) Az új körzetesítés társadalmi ára. - Kritika. 1. 2-5. o.

Lukács L. (szerk.) (2004) Kistérségi közoktatási feladatellátó társulások. Oktatási Minisztérium, Budapest.

Oktatás-statistikai Évkönyv 2008-2009 (2009) OKM, Budapest. http://www.nefmi.gov.hu/letolt/ statisztika/okt_evkonyv_2008_2009_091207.pdf

OKM (2008) Országos kompetenciamérés 2008. Országos jelentés. OKM, Budapest. 
Péteri G. (2005) Költségek - eredmények - hatékonyság. http://ofi.hu/tudastar/onkormanyzatkozoktatas/peteri-gabor-koltsegek

Radó P. (szerk.) (2004) Fenntartható-e a közoktatás? Hatékonysági szempontok érvényesítése a közoktatásban. OKI, Budapest.

Radó P. (szerk.) (2006) Kistelepülések kisiskolái. Az Oktatáspolitikai Elemzések Központja nyilvános közpolitikai elemzése. Sulinova, Budapest.

Rácz K. (2008) Településközi kooperációk és közszolgáltatások a Felső-Tisza vidéken. - Kovács K.Somlyódyné Pfeil E. (szerk.) Függöben. Közszolgáltatás-szervezés a kistelepülések világában. CompLex Kiadó Kft., Budapest. 305-332. o.

Semjén A. (2005) Az oktatási rendszer külső hatékonysága: a gazdaság és a munkaerőpiac elvárásai. http://ofi.hu/tudastar/hatekonysagi-problemak/oktatasi-rendszer-kulso

Setényi J. (2004) Kistérségi minőségfejlesztés a borsodi tapasztalatok alapján. - Lukács L. (szerk). Kistérségi közoktatási feladatellátó társulások. Oktatási Minisztérium, Budapest. 259-273. o.

Somlyódyné Pfeil E. (2008) Települési és körzeti feladatellátás, valamint a közigazgatási középszint problematikája hazai és nemzetközi tapasztalatok alapján. - Kovács K.-Somlyódyné Pfeil E. (szerk.) Függőben. Közszolgáltatás-szervezés a kistelepülések világában. CompLex Kiadó Kft., Budapest. 97-122. o.

Váradi M.M. (2008a) Fontolva haladók: többcélú kistérségi társulás és közoktatás a Zalaszentgróti kistérségben. - Kovács K.-Somlyódyné Pfeil E. (szerk.) Függőben. Közszolgáltatás-szervezés a kistelepülések világában. CompLex Kiadó Kft., Budapest. 333-370. o.

Váradi M.M. (2008b) Kistelepülések és kisiskolák: közoktatási tapasztalatok a kistérségi társulásokban. Kovács K.-Somlyódyné Pfeil E. (szerk.) Függőben. Közszolgáltatás-szervezés a kistelepülések világában. CompLex Kiadó Kft., Budapest. 155-182. o.

Varga J. (2008) Az iskolaügy intézményrendszere, finanszírozása. - Fazekas K.-Köllő J.-Varga J. (szerk.) Zöld könyv a magyar közoktatás megújításáért 2008. Ecostat, Budapest. 235-258. o.

Virág T. (2006) A gettósodó térség. - Szociológiai Szemle. 1. 60-76. o.

Virág T. (2008) Látlelet az északi perifériáról: oktatás-szervezés az Edelényi kistérségben. - Kovács K.Somlyódyné Pfeil E. (szerk.) Függöben. Közszolgáltatás-szervezés a kistelepülések világában. CompLex Kiadó Kft, Budapest. 425-444. o.

\section{A PRESSURE TO CO-OPERATE OR CLOSE: PUBLIC EDUCA- TION MANAGEMENT IN THE RANKS OF MULTIFUNCTIONAL LOCAL GOVERNMENT ASSOCIATIONS}

\section{KATALIN KOVÁCS}

The first part of the paper discusses the factors that increased the pressure on rural municipalities in service delivery particularly in provisioning public education (demographic decline, diminishing state subsidies). The second part of the article deals with some aspects of public services provided by the so-called multi-functional local government associations (MLGA) at LAU-1 (micro-regional) level. Regional differences generated by the variety of settlement patterns of the NUTS-2 regions as well as the impacts of the MLGA-s are discussed in detail. The sharp drop of schools run by villages signals the losers of the impacts of the 2004 Act on MLGAs and other government interventions, whilst the winners are identified as well: joint operation of schools by maintenance associations redoubled between 2004 and 2008, MLGAs themselves also appeared amongst the educational service providers, whilst the role of NGOs and churches in operating village schools grew significantly as well. The author is convinced about the importance of co-operation in delivering public services particularly in areas of scattered and small villages. However, she warns that the fast and pressed school closures as well as the forced creation of associations on extended territories amongst faraway partners might bring negative outcomes therefore a gradual, tolerant and place-tailored approach should be applied. 